\title{
The Investigation of a Weak Form of the Efficient Market Hypothesis: Evidence From Stock Markets in the European Union
}

\author{
Jacek Karasiński*
}

\begin{abstract}
Summary
The purpose of this article is to examine whether returns of main indexes of selected stock exchanges in the European Union are subject to the random walk model proposed by L. Bacheliere in 1900, which is considered by many researchers to be a synonym of a weak form of the efficient market. The research was conducted for the main indexes of eight selected European stock exchanges representing markets of a different capitalisation. In order to check whether the level of informational efficiency was stable in a whole research period, namely in the years 2000-2017, the research period was divided into three equal six years sub-periods. To test a weak form of the efficient market hypothesis (EMH), four different tests of returns distribution normality were done for daily, weekly, monthly and quarterly intervals. The conducted study allowed for rejecting the null hypothesis saying that returns are subject to the random walk model proposed by L. Bacheliere which leads to normal distribution. Moreover, some significant differences between the research periods occurred. Nonetheless as the random walk model seems to be too strict even for the biggest European markets, it is proposed to test whether the returns can be subject to other stable distributions like the Pareto distribution, which gives higher probability to extremely low and high returns of what resembles actual price fluctuations of financial markets.
\end{abstract}

Keywords: Efficient market hypothesis, Weak form efficiency, Stock markets, The European Union, Random walk

JEL: E44, G10, G14

\section{INTRODUCTION}

The high formalization of information transmission mechanisms on the regulated markets in the European Union aids a common and equal access to information, as well as safety and transparency of trading (Dziawgo, 2011). The mechanisms of the information transmission mentioned are to the greatest extent responsible for informational efficiency of the market, as on the efficient market the prices change due to new information and the situation expected by investors in the future. Moreover, on the efficient market the prices stay unchanged until the new, economically significant information is published (Czekaj, 2014). The abovementioned results from the definition of the efficient market proposed by E. Fama (1970), which states that available information is fully reflected by the prices. What is more E. Fama (1970) distinguished three types of informational market efficiency depending on the set of information - namely a weak, semi-strong and strong informational market efficiency. The weak form of the efficient market hypothesis (EMH) formulated by E. Fama (1970) and M. C. Jensen (1978) states that the current prices of financial assets reflect historical information and the expected situation, which means that the current prices vary randomly in a way impossible to predict (Kilon and Jamróz, 2015). The first model of the stochastic process of stock prices fluctuation, called a random walk model, was proposed by L. Bacheliere in 1900 . His model is considered by many researchers to be a synonym of informational efficiency of the market in a weak form, which indicates that the short-term returns fluctuations are random and fully reflect any information at any time (Czekaj, 2014).

The aim of this paper is to examine whether returns of the main indexes of selected European stock exchanges are efficient in a weak form. Taking into account that the random walk model

\footnotetext{
Faculty of Management, University of Warsaw, Poland, https://orcid.org/0000-0003-4326-5044, e-mail: jkarasinski@ wz.uw.edu.pl
} 
of L. Bacheliere from 1900 leads to a normal distribution, in order to check whether the selected indexes were efficient in a weak form, four chosen tests of returns distribution normality were done for four different quotation intervals. As is typical for the research on market efficiency, the null hypothesis was that the markets were efficient. The research was conducted for the main indexes of eight selected stock exchanges in the European Union representing markets of a different capitalisation. In order to check whether the level of informational efficiency was stable in a whole research period, namely in the years 2000-2017, the research period was divided into three equal six years sub-periods.

\section{RESEARCH ON THE WEAK FORM OF THE EFFICIENT MARKET HYPOTHESIS}

The stock markets' weak form efficiency tests are willingly conducted on many markets all over the world. There are several main reasons for the large number of studies related to the stock markets' weak form efficiency testing. First, the markets are changing and thereupon their informational efficiency is changing as well. What is more, new markets come into being. Secondly, data necessary to conduct weak form efficiency tests is widely and easily accessible. Any researcher can easily examine the informational efficiency of any market in the world. Thirdly, weak form informational efficiency tests can be run quickly for many different shares, indexes and markets once the researcher possesses advanced statistical and econometric knowledge.

In order to test the weak form efficient market hypothesis, which is far more often tested than the semi-strong and strong one, the researchers conduct tests which can be divided into three different groups. The first group pertains to tests based on technical analysis. These methods use tools provided by technical analysis to predict the prices of financial assets. When the predictions are accurate, the hypothesis of the weak form efficient market is rejected. The second group relates to random walk testing and usually the researchers use autocorrelation tests, runs tests and unit root tests. When the returns are not subject to random walk, the hypothesis of the weak form efficient market is rejected. The third group pertains to searching for calendar and seasonal effects. When some regular calendar and seasonal effects are spotted, the hypothesis of the weak form efficient market is rejected (Czekaj, 2014).

The research of M. R. Borges (2010) can be an example of a study devoted to different European markets. She investigated weak form informational efficiency for stock market indexes in the UK, France, Germany, Spain, Greece and Portugal, from January 1993 to December 2007 using runs tests and joint variance ratio tests. Results varied depending on the country and stock returns frequency. The hypothesis of the weak form market efficiency was rejected on daily data for Portugal and Greece as well as for France and the UK on weekly data. The hypothesis wasn't rejected for Germany and Spain. A Spanish market turned out to be the most efficient one. A comprehensive research of fifteen European emerging stock markets conducted by G. Smith (2012) in the period from February 2000 to December 2009 for daily data used rolling window variance ratio tests based on returns and signs with wild bootstrapped p-values. The results reached varied across the countries. The most efficient ones were the Turkish, UK, Hungarian and Polish markets. The least efficient ones were the Ukrainian, Maltese and Estonian stock markets. J. Kilon and P. Jamróz (2015) made an attempt to answer the question of whether for the Warsaw Stock Exchange the weak form of the efficient market hypothesis can be considered true, and what its informational efficiency looks like compared to selected stock exchanges of Baltic Sea countries. The researchers performed autocorrelation tests, series tests and unit root tests in the period from January 2000 to December 2014 for nine different stock indexes including four Polish ones and five from different Baltic Sea countries. The results reached indicate some inefficiencies for all markets examined, however they do not permit to completely reject the hypothesis of a weak 
form efficiency. The main conclusion made by the authors is that the selected active investment strategies can be successful for some groups of shares on all markets examined. It especially pertains to indexes containing small and medium-sized companies, which confirms the results of other studies.

With regard to studies on the weak form efficiency of stock markets from other parts of the world, W. Abdmoulah (2010) examined eleven Arab stock markets in a ten year period ending in March 2009 using the GARCH-M $(1,1)$ approach. Results of the research indicate that all markets show high sensitivity to past shocks and are found to be weak form inefficient. What is more, no significant improvement of market informational efficiency can be seen. The author advises that in order to enhance the Arab markets' efficiency, some actions like liquidity improvement, enhancement of investment culture and spreading of institutional trading need to be undertaken. M. A. M. Al Janabi, A. Hatemi and M. Irandoust (2010) examined whether the Gulf Cooperation Council (GCC) stock markets are informationally efficient with regard to oil and gold price shocks during the period 2006-2008. The empirical findings revealed that the GCC equity markets are informationally efficient with regard to gold and oil price indexes. The main objective of the study by S. Arshad, S. A. R. Rizvi, G. M. Ghani and J. Duasa (2016) was to examine the weak form efficiency of Organization of Islamic Conference (OIC) member stock markets. The research was conducted for 11 markets and covered the period of 1998-2012. The main conclusion was that the overall efficiency varied across the countries for the short and long term, it was however improving over the years examined. The weak form market efficiency comparison of Islamic and non-Islamic stock indices made by O. M. Al-Khazali, G. Leduc and M. S. Alsayed (2016) indicated that overall the non-Islamic indices were more efficient than their Islamic counterparts. Nevertheless, during the periods of bearish stock markets all indices showed the same level of efficiency. In four subperiods of bullish and bearish stock markets over the period from 1997 to 2012 the study applied the automatic portmanteau test, the test for the martingale difference hypothesis as well as the automatic variance ratio test.

J. Appiah-Kusi and K. Menyah (2003) investigated the weak form pricing efficiency of eleven African stock markets. Results received varied across the countries. Markets in Nigeria, South Africa, Botswana, Ghana, Ivory Coast and Swaziland are not consistent with weak form efficiency in contrast to markets in Egypt, Kenya, Zimbabwe, Mauritius and Morocco. Another study by M. A. Magnusson and B. Wydick (2002) related to the African markets tested informational efficiency of the eight largest African markets using random walk tests. Results were compared with similar tests on emerging stock markets in South-East Asia and Latin America. Results reached indicate that the emerging African stock markets are more efficient in comparison to other emerging stock markets.

J. H. Kim and A. Shamsuddin (2008) tested weak form efficiency for a group of Asian markets using multiple variance ratio tests based on the wild bootstrap and signs. Hong Kong, Japanese, Korean and Taiwanese markets turned out to be efficient in the weak form. The results received showed that Singaporean and Thai markets have become efficient after the Asian crisis. The weak form efficiency hypothesis had to be rejected for Indonesia, Malaysia and the Philippines. Another research related to Asian markets by E. J. A. Lima and B. M. Tabak (2004) tests the random walk hypothesis for China, Hong Kong and Singapore. The results indicate that Chinese and Hong Kong Class A shares are weak form efficient in opposite to Singapore and Chinese Class B stocks. The authors suggest that liquidity and market capitalization may play a role in explaining results of weak form efficiency tests. The influence of the financial crisis on East Asian markets was examined by S.A.R. Rizvi and S. Arshad (2016). They applied the multifractal detrended fluctuation analysis to derive the efficiency measure for comparative analysis of crisis periods with pre-crisis and postcrisis periods. They found that the financial crisis had a negative impact on the weak form market 
efficiency. They also found that the crisis impact varied based on the economic structure of the economies.

Many studies on the weak form efficiency of markets testing random walk use autocorrelation tests, runs tests and unit root tests. However, results of studies focused on prices stationarity testing using unit root tests have low informational value. What is more, commonly used autocorrelation tests have been developed under the assumption of linearity and normality of the returns analysed. Because of that, when returns are not normally distributed, or a given study does not provide any information on returns normality, the results of autocorrelation tests have to be treated with caution (Czekaj, 2014).

\section{RESEARCH METHOD}

As it was already mentioned, the first model of stochastic process of stock prices fluctuation called a random walk model proposed by L. Bacheliere in 1900 is considered by many researchers to be a synonym of informational efficiency of the market in a weak form. It can be described by the following equation:

$$
y_{t}=y_{t-1}+\varepsilon_{t}, \quad \varepsilon_{t} i d d(0,1)
$$

where $y_{t-1}$ is price in the period $t-1, y_{t}$ is the price in the period $t$ and $\varepsilon_{t}$ is a random component reflecting the influence of new information on the price change. The main indication of the model is that the short-term returns fluctuations are random, and the prices immediately reflect accessible information. After proper transformation of the formula presented above, a density function of the normal distribution is received, which means that if the returns are subject to random walk model they have to be normally distributed (Czekaj, 2014).

$$
P(t, i)=\sqrt{\frac{2}{t \pi}} \exp \left(-\frac{\left(i-\frac{t}{2}\right)^{2}}{t}\right) d i
$$

In order to achieve the goal of this study, the selected tests of returns normality were conducted, namely the Kolmogorov-Smirnov test, the Lilliefors test, the Shapiro-Wilk test and the D'AgostinoPearson test. The null hypothesis stated that the empirical returns distribution $F$ was compatible with the normal distribution $N\left(\hat{u}, \hat{\sigma}^{\in}\right)$. It was rejected for the benefit of the alternative hypothesis stating that the empirical returns distribution $F$ was not compatible with the normal distribution $N\left(\hat{u}, \hat{\sigma}^{\in}\right)$ when the p-value resulting from the normality test was less than the significance level of $\alpha=0.05$.

$$
\begin{aligned}
& H_{0}: F=N\left(\hat{u}, \hat{\sigma}^{\in}\right), \\
& H_{1}: F \neq N\left(\hat{u}, \hat{\sigma}^{\in}\right) .
\end{aligned}
$$

The research was conducted for the main indexes of eight selected stock exchanges in the European Union, representing markets of a different capitalisation. The selected indexes are presented in table 1. In order to check whether the level of informational efficiency was stable in a whole research period, namely in the years 2000-2017, the research period was divided into three equal six years sub-periods. The first sub-period was 2000-2005, the second one was 2006-2011 and the third one was 2012-2017. Moreover, the normality tests were performed for four different quotation intervals, namely for daily, weekly, monthly and quarterly intervals. 
Table 1. Main indexes of selected stock exchanges in the European Union

\begin{tabular}{|c|c|c|c|c|c|}
\hline Index & Stock exchange & Country & Index & Stock exchange & Country \\
\hline ATX & Vienna Stock Exchange & Austria & HEX & Helsinki Stock Exchange & Finland \\
\hline BUX & Budapest Stock Exchange & Hungary & IBEX 35 & Madrid Stock Exchange & Spain \\
\hline DAX & Frankfurt Stock Exchange & Germany & OMXS30 & Stockholm Stock Exchange & Sweden \\
\hline FTSE 100 & London Stock Exchange & UK & WIG & Warsaw Stock Exchange & Poland \\
\hline
\end{tabular}

Source: Own elaboration.

All necessary data pertaining to quotations of indexes has been obtained from the website stooq. pl. Statistical tests of returns distributions normality have been performed in PQStat, a statistical software.

\section{EMPIRICAL RESULTS}

The results of the normality tests for returns distributions of selected indexes in specified subperiods for four different quotation intervals are presented in table 3. Cases in which there were no grounds to reject the null hypothesis (empirical returns distribution was compatible with the normal distribution) are bolded and marked as H0. Cases in which the null hypothesis had to be rejected at the significance level of $\alpha=0.05$ are marked as H1. In order to make the analysis of the results easier, in table 2, the percentage of cases in which there were no grounds to reject the null hypothesis is presented. It's worth adding that the table 2 aggregates cases in which there were no grounds for rejecting the null hypothesis for many indexes, but still divides them into specified sub-periods.

The results indicate that in almost all cases of daily intervals, the null hypothesis had to be rejected for the benefit of the alternative one. Only in the case of BUX index from the Budapest Stock Exchange in Hungary in the period 2000-2005, according to the Kolmogorov-Smirnov test, daily returns seemed to be distributed normally. In the following research periods the indications of the Kolmogorov-Smirnov test for the BUX index were different. The next main conclusion, which can be easily made on the basis of the results reached, is that the percentage of cases in which there were no grounds to reject the null hypothesis increased along with the decrease of the returns frequency.

Table 2. Percentage of cases in which there were no grounds to reject the null hypothesis

\begin{tabular}{|c|c|c|c|c|c|c|c|c|c|c|c|c|c|c|c|c|}
\hline \multirow{2}{*}{$\frac{\text { Test }}{\text { Period }}$} & \multicolumn{4}{|c|}{ Kolmogorov-Smirnov \% } & \multicolumn{4}{|c|}{ Lilliefors \% } & \multicolumn{4}{|c|}{ Shapiro-Wilk \% } & \multicolumn{4}{|c|}{ D'Agostino-Pearson \% } \\
\hline & d. & w. & $\mathrm{m}$. & q. & d. & W. & $\mathrm{m}$. & q. & d. & $\mathrm{w}$. & $\mathrm{m}$ & q. & d. & w. & $\mathrm{m}$. & q. \\
\hline $2000-2005$ & 13 & 100 & 100 & 100 & 0 & 50 & 100 & 88 & 0 & 25 & 75 & 88 & 0 & 25 & 75 & 88 \\
\hline 2006-2011 & 0 & 0 & 100 & 100 & 0 & 0 & 63 & 100 & 0 & 0 & 50 & 88 & 0 & 0 & 38 & 100 \\
\hline 2012-2017 & 0 & 100 & 100 & 100 & 0 & 75 & 63 & 75 & 0 & 13 & 75 & 100 & 0 & 25 & 75 & 100 \\
\hline
\end{tabular}

Source: Own elaboration.

The conclusions are in line with the conclusions of J. Czekaj (2014) made on the basis of results reached in the research conducted on the Warsaw Stock Exchange. The phenomenon observed mainly the results from the growing sample of returns, namely when the frequency of returns is 
Table 3. Results of normality tests for returns of main indexes of selected stock exchanges in the EU

\begin{tabular}{|c|c|c|c|c|c|c|c|c|c|c|c|c|c|c|c|c|c|c|c|}
\hline \multicolumn{4}{|c|}{ Statistical test } & \multicolumn{4}{|c|}{ Kolmogorov-Smirnov } & \multicolumn{4}{|c|}{ Lilliefors } & \multicolumn{4}{|c|}{ Shapiro-Wilk } & \multicolumn{4}{|c|}{ D'Agostino-Pearson } \\
\hline Index & Stock exchange & Country & Period & d. & w. & $\mathrm{m}$. & $\mathrm{q}$. & d. & w. & $\mathrm{m}$. & $\mathrm{q}$. & d. & w. & $\mathrm{m}$. & $\mathrm{q}$. & d. & w. & $\mathrm{m}$. & q. \\
\hline ATX & Vienna SE & Austria & \multirow{8}{*}{$2000-2005$} & H1 & $\mathrm{HO}$ & $\mathrm{H} 0$ & $\mathrm{HO}$ & $\mathrm{H} 1$ & $\mathrm{H} 0$ & $\mathrm{H} 0$ & $\mathrm{Ho}$ & $\mathrm{H} 1$ & Ho & $\mathrm{HO}$ & $\mathrm{H} 0$ & $\mathrm{H} 1$ & $\mathrm{H} 0$ & $\mathrm{H} 0$ & $\mathrm{H} 0$ \\
\hline BUX & Budapest SE & Hungary & & $\mathrm{H} 0$ & $\mathrm{HO}$ & $\mathrm{H} 0$ & $\mathrm{H} 0$ & $\mathrm{H} 1$ & $\mathrm{H} 0$ & $\mathrm{H} 0$ & $\mathrm{HO}$ & $\mathrm{H} 1$ & $\mathrm{H} 0$ & $\mathrm{HO}$ & $\mathrm{H} 0$ & $\mathrm{H} 1$ & $\mathrm{HO}$ & $\mathrm{H} 0$ & $\mathrm{HO}$ \\
\hline DAX & Frankfurt SE & Germany & & $\mathrm{H} 1$ & $\mathrm{HO}$ & $\mathrm{H} 0$ & $\mathrm{H} 0$ & H1 & $\mathrm{H} 0$ & $\mathrm{H} 0$ & $\mathrm{HO}$ & $\mathrm{H} 1$ & $\mathrm{H} 1$ & H1 & $\mathrm{H} 0$ & $\mathrm{H} 1$ & $\mathrm{H} 1$ & $\mathrm{H} 1$ & $\mathrm{H} 1$ \\
\hline FTSE 100 & London SE & UK & & $\mathrm{H} 1$ & $\mathrm{H} 0$ & $\mathrm{H} 0$ & Ho & H1 & $\mathrm{H} 1$ & $\mathrm{H} 0$ & Ho & H1 & $\mathrm{H} 1$ & H1 & $\mathrm{H} 0$ & H1 & H1 & H1 & $\mathrm{HO}$ \\
\hline HEX & Helsinki SE & Finland & & $\mathrm{H} 1$ & $\mathrm{H} 0$ & H0 & Ho & $\mathrm{H} 1$ & $\mathrm{H} 1$ & Ho & $\mathrm{H} 0$ & $\mathrm{H} 1$ & $\mathrm{H} 1$ & $\mathrm{H} 0$ & Ho & $\mathrm{H} 1$ & $\mathrm{H} 1$ & Ho & $\mathrm{Ho}$ \\
\hline IBEX 35 & Madrid SE & Spain & & $\mathrm{H} 1$ & $\mathrm{HO}$ & $\mathrm{H} 0$ & H0 & $\mathrm{H} 1$ & H1 & $\mathrm{H} 0$ & $\mathrm{H} 0$ & H1 & H1 & $\mathrm{H} 0$ & $\mathrm{H} 0$ & H1 & $\mathrm{H} 1$ & $\mathrm{H} 0$ & $\mathrm{HO}$ \\
\hline OMXS30 & Stockholm SE & Sweden & & $\mathrm{H} 1$ & $\mathrm{H} 0$ & $\mathrm{H} 0$ & $\mathrm{H} 0$ & $\mathrm{H} 1$ & $\mathrm{H} 1$ & $\mathrm{H} 0$ & $\mathrm{H} 1$ & $\mathrm{H} 1$ & $\mathrm{H} 1$ & $\mathrm{HO}$ & $\mathrm{H} 1$ & H1 & $\mathrm{H} 1$ & $\mathrm{H} 0$ & $\mathrm{HO}$ \\
\hline WIG & Warsaw SE & Poland & & H1 & $\mathrm{HO}$ & $\mathrm{H} 0$ & $\mathrm{H} 0$ & H1 & $\mathrm{H} 0$ & H0 & $\mathrm{HO}$ & H1 & H1 & $\mathrm{HO}$ & $\mathrm{H} 0$ & H1 & H1 & $\mathrm{H} 0$ & $\mathrm{HO}$ \\
\hline ATX & Vienna SE & Austria & \multirow{8}{*}{ 2006-2011 } & $\mathrm{H} 1$ & $\mathrm{H} 1$ & H0 & Ho & $\mathrm{H} 1$ & $\mathrm{H} 1$ & $\mathrm{H} 1$ & $\mathrm{H} 0$ & $\mathrm{H} 1$ & $\mathrm{H} 1$ & $\mathrm{H} 1$ & Ho & $\mathrm{H} 1$ & $\mathrm{H} 1$ & $\mathrm{H} 1$ & $\mathrm{Ho}$ \\
\hline BUX & Budapest SE & Hungary & & $\mathrm{H} 1$ & $\mathrm{H} 1$ & $\mathrm{H} 0$ & $\mathrm{H} 0$ & H1 & $\mathrm{H} 1$ & $\mathrm{H} 0$ & $\mathrm{HO}$ & H1 & $\mathrm{H} 1$ & H1 & $\mathrm{H} 0$ & H1 & $\mathrm{H} 1$ & H1 & $\mathrm{H} 0$ \\
\hline DAX & Frankfurt SE & Germany & & $\mathrm{H} 1$ & $\mathrm{H} 1$ & $\mathrm{H} 0$ & Ho & $\mathrm{H} 1$ & $\mathrm{H} 1$ & $\mathrm{H} 1$ & Ho & $\mathrm{H} 1$ & $\mathrm{H} 1$ & $\mathrm{H} 1$ & $\mathrm{H} 1$ & $\mathrm{H} 1$ & $\mathrm{H} 1$ & H1 & $\mathrm{Ho}$ \\
\hline FTSE 100 & London SE & UK & & $\mathrm{H} 1$ & $\mathrm{H} 1$ & $\mathrm{H} 0$ & $\mathrm{H} 0$ & H1 & $\mathrm{H} 1$ & $\mathrm{H} 0$ & Ho & $\mathrm{H} 1$ & $\mathrm{H} 1$ & $\mathrm{H} 0$ & $\mathrm{H} 0$ & $\mathrm{H} 1$ & $\mathrm{H} 1$ & $\mathrm{H} 0$ & $\mathrm{HO}$ \\
\hline HEX & Helsinki SE & Finland & & $\mathrm{H} 1$ & $\mathrm{H} 1$ & $\mathrm{H} 0$ & $\mathrm{H} 0$ & $\mathrm{H} 1$ & $\mathrm{H} 1$ & $\mathrm{H} 0$ & $\mathrm{HO}$ & $\mathrm{H} 1$ & $\mathrm{H} 1$ & $\mathrm{Ho}$ & Ho & $\mathrm{H} 1$ & $\mathrm{H} 1$ & $\mathrm{H} 0$ & $\mathrm{Ho}$ \\
\hline IBEX 35 & Madrid SE & Spain & & $\mathrm{H} 1$ & $\mathrm{H} 1$ & $\mathrm{H} 0$ & $\mathrm{H} 0$ & $\mathrm{H} 1$ & $\mathrm{H} 1$ & Ho & $\mathrm{H} 0$ & $\mathrm{H} 1$ & $\mathrm{H} 1$ & $\mathrm{Ho}$ & $\mathrm{H} 0$ & $\mathrm{H} 1$ & $\mathrm{H} 1$ & $\mathrm{H} 0$ & $\mathrm{HO}$ \\
\hline OMXS30 & Stockholm SE & Sweden & & $\mathrm{H} 1$ & $\mathrm{H} 1$ & $\mathrm{H} 0$ & $\mathrm{H} 0$ & $\mathrm{H} 1$ & $\mathrm{H} 1$ & $\mathrm{H} 1$ & $\mathrm{HO}$ & $\mathrm{H} 1$ & $\mathrm{H} 1$ & $\mathrm{H} 1$ & $\mathrm{H} 0$ & H1 & H1 & H1 & $\mathrm{H} 0$ \\
\hline WIG & Warsaw SE & Poland & & $\mathrm{H} 1$ & $\mathrm{H} 1$ & $\mathrm{H} 0$ & $\mathrm{H} 0$ & H1 & $\mathrm{H} 1$ & $\mathrm{H} 0$ & $\mathrm{HO}$ & $\mathrm{H} 1$ & $\mathrm{H} 1$ & $\mathrm{H} 0$ & $\mathrm{H} 0$ & H1 & $\mathrm{H} 1$ & H1 & $\mathrm{H} 0$ \\
\hline ATX & Vienna SE & Austria & \multirow{8}{*}{$2012-2017$} & $\mathrm{H} 1$ & $\mathrm{HO}$ & Ho & Ho & $\mathrm{H} 1$ & Ho & $\mathrm{H} 1$ & $\mathrm{HO}$ & $\mathrm{H} 1$ & Ho & $\mathrm{H} 1$ & Ho & $\mathrm{H} 1$ & $\mathrm{H} 0$ & $\mathrm{H} 0$ & $\mathrm{HO}$ \\
\hline BUX & Budapest SE & Hungary & & $\mathrm{H} 1$ & $\mathrm{H} 0$ & $\mathrm{H} 0$ & H0 & $\mathrm{H} 1$ & $\mathrm{H} 0$ & $\mathrm{H} 0$ & $\mathrm{H} 0$ & $\mathrm{H} 1$ & $\mathrm{H} 1$ & $\mathrm{HO}$ & $\mathrm{H} 0$ & $\mathrm{H} 1$ & $\mathrm{H} 1$ & $\mathrm{H} 0$ & $\mathrm{HO}$ \\
\hline DAX & Frankfurt SE & Germany & & $\mathrm{H} 1$ & $\mathrm{HO}$ & $\mathrm{H} 0$ & $\mathrm{H} 0$ & $\mathrm{H} 1$ & $\mathrm{H} 1$ & $\mathrm{H} 0$ & $\mathrm{HO}$ & $\mathrm{H} 1$ & $\mathrm{H} 1$ & $\mathrm{H} 0$ & $\mathrm{H} 0$ & $\mathrm{H} 1$ & $\mathrm{H} 1$ & $\mathrm{H} 0$ & $\mathrm{HO}$ \\
\hline FTSE 100 & London SE & UK & & $\mathrm{H} 1$ & $\mathrm{HO}$ & $\mathrm{H} 0$ & $\mathrm{H} 0$ & $\mathrm{H} 1$ & $\mathrm{H} 0$ & $\mathrm{H} 1$ & $\mathrm{H} 1$ & H1 & $\mathrm{H} 1$ & $\mathrm{H} 1$ & $\mathrm{H} 0$ & $\mathrm{H} 1$ & H1 & $\mathrm{H} 1$ & $\mathrm{HO}$ \\
\hline HEX & Helsinki SE & Finland & & $\mathrm{H} 1$ & H0 & Ho & Ho & H1 & Ho & Ho & Ho & H1 & H1 & H0 & Ho & H1 & H1 & Ho & $\mathrm{Ho}$ \\
\hline IBEX 35 & Madrid SE & Spain & & $\mathrm{H} 1$ & $\mathrm{HO}$ & $\mathrm{H} 0$ & H0 & H1 & $\mathrm{H} 0$ & $\mathrm{H} 0$ & $\mathrm{H} 0$ & $\mathrm{H} 1$ & $\mathrm{H} 1$ & $\mathrm{H} 0$ & $\mathrm{H} 0$ & H1 & $\mathrm{H} 0$ & $\mathrm{H} 0$ & $\mathrm{HO}$ \\
\hline OMXS30 & Stockholm SE & Sweden & & $\mathrm{H} 1$ & $\mathrm{H} 0$ & H0 & Ho & $\mathrm{H} 1$ & H1 & H0 & $\mathrm{H} 0$ & H1 & H1 & $\mathrm{H} 0$ & $\mathrm{H} 0$ & H1 & H1 & $\mathrm{H} 0$ & $\mathrm{HO}$ \\
\hline WIG & Warsaw SE & Poland & & $\mathrm{H} 1$ & $\mathrm{H} 0$ & $\mathrm{H} 0$ & Ho & H1 & $\mathrm{H} 0$ & H1 & H1 & H1 & H1 & Ho & H0 & H1 & H1 & H1 & $\mathrm{HO}$ \\
\hline
\end{tabular}

Source: Own elaboration. 
higher, the sample is bigger and when the sample is bigger, there is more evidence to reject the null hypothesis.

Looking at the percentage of cases in which there were no grounds to reject the null hypothesis in particular sub-periods, it is easy to notice some differences between them. Firstly, in contrast to the periods 2000-2005 and 2012-2017, the period 2006-2011 has no efficient stock indexes for weekly intervals according to all four statistical tests. For monthly intervals, the period 2006-2011 has fewer cases of null hypothesis rejections or their percentage is the same as in the case of two other periods. This phenomenon can result from the global financial crisis which began in 2007, and which could influence the informational efficiency of the financial markets. It's also worth to add that overall the percentage of the null hypothesis rejections is noticeably lower in the case of the Kolmogorov-Smirnov test and the Lilliefors test. It results from the nature of the statistical tests applied. The Kolmogorov-Smirnov test and the Lilliefors test both are from the same group of nonparametric tests of distributions compatibility, verifying the distance between the empirical cumulative distribution function and the normal one. The third test used, namely the Shapiro-Wilk test, belongs to the group of tests based on the statistical measures of position quantile-quantile. The fourth test used, namely the D'Agostino-Pearson test, is based on a special feature of the normal distribution, i.e. skewness and kurtosis equal to zero.

Taking into account that the measures were done for each of the eight indexes, four intervals, three sub-periods, and that four different test were applied, the total number of tests done for each index was fourty-eight. The BUX index from the Budapest Stock Exchange in Hungary had the greatest number of not rejected null hypotheses, namely twenty-nine. The fewest number of not rejected null hypotheses belonged to the DAX index from the Frankfurt Stock Exchange in Germany, and their number was twenty.

\section{CONCLUSIONS}

The results of the research show that in the case of almost all indexes for daily returns frequency, and the higher one the hypothesis of normally distributed returns, has to be rejected. In result they cannot be considered as being subject to the random walk model of L. Bacheliere from 1900, and the markets cannot be considered weak form efficient as well. The results are in line with these of J. Czekaj (2014), reached in the research done on the Warsaw Stock Exchange. Additionally, in his research, J. Czekaj (2014) presented the kurtosis of returns distributions which is commonly used in financial econometrics to characterise the tails. It turned out that the tails of returns distributions were fat and that was why the normal distribution seemed not to be good for describing the dynamics of financial asset prices fluctuations. As the normal distribution belongs to a group of stable distributions, it is proposed to test whether the returns can be subject to other stable distributions like the Pareto distribution, which gives higher probability to extremely low and high returns which resembles actual price fluctuations on financial markets.

\section{Literature}

Abdmoulah, W. (2010). Testing the evolving efficiency of Arab stock markets. International Review of Financial Analysis, 19(1), 25-34. doi:10.1016/j.irfa.2009.11.004

Al Janabi, M. A. M., Hatemi-J, A. \& Irandoust, M. (2010). An empirical investigation of the informational efficiency of the GCC equity markets: Evidence from bootstrap simulation. International Review of Financial Analysis, 19(1), 47-54. doi:10.1016/j.irfa.2009.11.002

Al-Khazali, O. M., Leduc, G., \& Alsayed, M. S. (2016). A Market Efficiency Comparison of Islamic and Non-Islamic Stock Indices. Emerging Markets Finance and Trade, 52(7), 1587-1605. doi:10.1080/15404 96X.2014.998572 
Appiah-Kusi, J. \& Menyah, K. (2003). Return predictability in African stock markets. Review of Financial Economics, 12(3), 247-270. doi:10.1016/S1058-3300(02)00073-3

Arshad, S., Rizvi, S. A. R., Ghani, G. M., \& Duasa, J. (2016). Investigating stock market efficiency: A look at OIC member countries. Research in International Business and Finance, 36, 402-413. doi:10.1016/j. ribaf.2015.09.026

Borges, M. R. (2010). Efficient market hypothesis in European stock markets. European Journal of Finance, 16(7), 711-726. doi:10.1080/1351847X.2010.495477

Czekaj, J. (2014). Efektywność giełdowego rynku akcji w Polsce z perspektywy dwudziestolecia. Warszawa: Polskie Wydawnictwo Ekonomiczne.

Dziawgo, D. (2011). Relacje inwestorskie. Ewolucja, funkcjonowanie, wyzwania. Warszawa: Wydawnictwo Naukowe PWN.

Fama, E. F. (1970). Efficient Capital Markets: A Review of Theory and Empirical Work. Journal of Finance, 25(2), 383-417. doi:10.2307/2325486

Jensen, M. C. (1978). Some Anomalous Evidence Regarding Market Efficiency. Journal of Financial Economics, 6(2-3), 95-101. doi: 10.1016/0304-405X(78)90025-9

Kilon, J. \& Jamróz, P. (2015). Informational (in)efficiency of the Polish Stock Exchange. Procedia - Social and Behavioral Sciences, 213, 390-396. doi: 10.1016/j.sbspro.2015.11.556

Kim, J. H. \& Shamsuddin, A. (2008). Are Asian stock markets efficient? evidence from new multiple variance ratio tests. Journal of Empirical Finance, 15(3), 518-532. doi:10.1016/j.jempfin.2007.07.001

Lima, E. J. A. \& Tabak, B. M. (2004). Tests of the random walk hypothesis for equity markets: Evidence from China, Hong Kong and Singapore. Applied Economics Letters, 11(4), 255-258. doi:10.1080/135048 50410001674911

Magnusson, M. A. \& Wydick, B. (2002). How efficient are Africa's emerging stock markets? Journal of Development Studies, 38(4), 141-156. doi:10.1080/00220380412331322441

Rizvi, S. A. R. \& Arshad, S. (2016). How does crisis affect efficiency? An empirical study of East Asian markets. Borsa Istanbul Review, 16(1), 1-8. doi:10.1016/j.bir.2015.12.003

Smith, G. (2012). The changing and relative efficiency of European emerging stock markets. European Journal of Finance, 18(8), 689-708. doi:10.1080/1351847X.2011.628682 